\title{
ĐẠC ĐIẺM SINH HỌC PHÂN TỬ VÀ MÓI LIÊN QUAN VỚI LÂM SÀNG CỦA TYP DENGUE 1 GÂY DỊCH NĂM 2017
}

\author{
Đặng Thị Thúy ${ }^{1, 凶}$, Lê Văn Duyệt ${ }^{1}$, Bùi Vũ Huy ${ }^{2}$ \\ ${ }^{1}$ Bệnh viện Bệnh nhiệt đới Trung ương \\ ${ }^{2}$ Trường Đại học Y Hà Nội
}

Tìm hiểu một số đặc điểm sinh học phân tử và mối liên quan với mức độ lâm sàng của DEN - 1 gây dịch năm 2017. Nghiên cứu đa trung tâm, từ 07 - 12/2017, gồm 188 bệnh nhân sốt xuất huyết dengue (SXHD) $\geq 6$ tuổi có xét nghiệm PCR (+) với DEN - 1, tại bệnh viện Bệnh Nhiệt đới Trung ương và bệnh viện Bệnh Nhiệt đới, TP.Hồ Chí Minh. Đã giải mã thành công hệ gen của 55 chủng DEN - 1 gây dịch năm 2017. Hệ gen gồm 10.697 nucleotide, mã hóa một khung đọc mở gồm 3392 axit min. Các chủng DEN - 1 đều thuộc genotype 1 và có mức độ biến đổi axit amin cao ở hầu hết các gen (4,6\%). Nguồn gốc vẫn là chủng DENV phân bố tại Việt Nam trước đây. Có mối liên quan giữa bốn vị trí biến đổi axit amin 67, 126 (NS2A); 94 (NS2B) và 821 (NS5) với SXHD nặng. Nghiên cứu làm sáng tỏ nguồn gốc, sự biến đổi di truyền của các chủng DEN - 1 gây bệnh tại Việt Nam và mối liên quan giữa các vị trí thay thế axit amin với mức độ lâm sàng.

Từ khóa: Hệ gen, dengue virus type 1 (DEN - 1), biến đổi axit amin.

\section{I. ĐẠT VẤN ĐÊ}

Sốt xuất huyết Dengue (SXHD) là bệnh truyền nhiễm cấp tính do các typ virus dengue gây nên. Theo thông báo của Tổ chức $Y$ tế thế giới, bệnh SXHD đã trở nên phổ biến trên toàn cầu với số trường hợp mắc tăng nhanh trong những thập kỷ qua. ${ }^{1}$ Tại khu vực Đông Nam Á, SXHD được ghi nhận là một trong mười nguyên nhân hàng đầu về tỷ lệ mắc bệnh và tử vong. ${ }^{1}$

Virus dengue (DENV) thuộc họ Flaviviridae, nhân là một sợi $A R N$ đơn dương. Hệ gen mã hóa cho ba protein cấu trúc (protein capsid $(C)$, protein màng $(M)$ và protein vỏ $(E)$ và bảy protein không cấu trúc (NS1, NS2A, NS2B, $N S 3, N S 4 A, N S 4 B$ và NS5) nằm giữa hai vùng không dịch mã 5'UTR và 3'UTR. Dựa vào sự khác biệt kháng nguyên DENV được chia thành 4 typ..$^{1,2}$ Giữa các typ DENV có sự tương đồng

Tác giả liên hệ: Đặng Thị Thúy,

Bệnh viện Nhiệt đới Trung ương

Email: dangthuy.nhtd@gmail.com

Ngày nhận: 13/09/2020

Ngày được chấp nhận: 11/01/2021
65 - 70\% trình tự axit amin, ngoài ra mỗi typ còn được chia thành các genotype. ${ }^{2}$ Trong những năm gần đây, một số nghiên cứu đã đề cập đến sự đa dạng di truyền của các DENV và mối liên quan giữa các biến thể di truyền với độc lực virus. ${ }^{3,4}$

Tại Việt Nam, SXHD đã trở thành dịch hàng năm và cả 4 typ DENV đã được xác định cùng lưu hành gây bệnh. ${ }^{5}$ Theo các số liệu thống kê, trong những năm gần đây số trường hợp mắc SXHD có xu hướng gia tăng và dịch bệnh cũng diễn biến phức tạp hơn. ${ }^{6-8}$ Vào năm 2017 một vụ dịch SXHD đã xảy ra, lan rộng hầu hết các tỉnh thành trong cả nước. Chỉ tính riêng tại miền Bắc Việt Nam đã ghi nhận có 59.063 trường hợp mắc SXHD, tăng gấp 8 lần so với năm 2016. Typ DEN - 1 đã được xác định là căn nguyên gây bệnh chính trong vụ dịch này. ${ }^{8}$ Để tìm hiểu đặc điểm gen di truyền của các chủng DEN - 1 trong vụ dịch năm 2017 và mối liên quan với các mức độ nặng trên lâm sàng, chúng tôi tiến hành nghiên cứu với mục tiêu mô tả đặc điểm sinh học phân tử và mối liên quan với lâm sàng 
của typ DEN - 1 gây dịch năm 2017".

\section{II. ĐỐI TƯỢNG VÀ PHƯƠNG PHÁP}

\section{1. Đối tượng}

288 bệnh nhân và mẫu bệnh phẩm được chẩn đoán xác định nhiễm DEN - 1 .

\section{Tiêu chuẩn chọn bệnh nhân:}

Bệnh nhân được chẩn đoán và phân loại lâm sàng SXHD theo tiêu chuẩn của Bộ y tế Việt Nam năm 2019. ${ }^{5}$

Có kết quả xét nghiệm PCR (+) với typ DEN - 1 .

Tiêu chuẩn loại trừ: Mẫu bệnh phẩm lấy từ bệnh nhân đang mắc các bệnh cấp tính khác hoặc bệnh nhân không đồng ý tham gia nghiên cứu.

\section{Phương pháp}

Địa điểm và thời gian nghiên cứu: Nghiên cứu được tiến hành từ 01/07/2017 - 31/12/2017, tại bệnh viện Bệnh Nhiệt đới Trung ương (BVNĐTƯ) và bệnh viện Bệnh Nhiệt đới - TP. Hồ Chí Minh (BVNĐ.TP HCM).

Thiết kết nghiên cứu: Nghiên cứu mô tả, đa trung tâm

Cách chọn mẫu: Chọn mẫu thuận tiện

Các bước tiến hành: Tại hai điểm nghiên cứu, bệnh nhân nghi ngờ SXHD, có xét nghiệm NS1 (+) nhập viện trong 3 ngày đầu của bệnh sẽ được chọn vào nghiên cứu. Mỗi bệnh nhân được lấy $3 \mathrm{ml}$ đề thực hiện xét nghiệm PCR nhằm xác định typ, đo tải lượng và giải trình tự gen.

Để xác định các biến đổi axit amin, mối quan hệ di truyền của các chủng DEN - 1 gây bệnh trong vụ dịch năm 2017 và xây dựng cây phát sinh loài, chúng tôi giải trình tự toàn bộ hệ gen của 55 chủng DEN - 1 có tải lượng virus $>10^{3}$ copies $/ \mathrm{ml}$. Để làm tham chiếu chúng tôi cũng tiến hành giải trình tự hệ gen của 18 chủng DEN - 1 (gồm 9 chủng gây bệnh năm 2015 và 9 chủng năm 2016).

Toàn bộ bệnh nhân tham gia nghiên cứu được theo dõi, điều trị tại bệnh viện ít nhất 10 ngày đầu của bệnh.

\section{Các quy trình kỹ thuật sử dụng trong} nghiên cứu

Bộ test QIAamp Viral RNA Mini Kits của hãng Qiagen (Germantown Qiagen - Mỹ) được sử dụng để tách $A R N$ của DENV. Kỹ thuật Realtime OneStep Reverse Transcription PCR (RT - PCR) với các bộ mồi/probe đặc hiệu dùng để xác định typ, tải lượng virus. Xét nghiệm được thực hiện theo hướng dẫn của nhà sản xuất và quy trình thường quy của Bệnh viện Nhiệt đới Trung ương.

Giải trình tự toàn bộ hệ gen được thực hiện trên hệ thống giải trình tự gen thế hệ mới (NGS - Next Generation Sequencing) MiSeq của hãng Illumina. ${ }^{9}$ Trình tự bộ gen virus được lắp ráp từ các đoạn đọc bằng phần mềm CLC, sử dụng trình tự tham chiếu là chủng DEN - 1 năm 1997 (GenBank NC_001477.1). Độ đọc lặp lại của từng nucleotide trên chuỗi gen được tính toán bằng phần mềm SAMtools.

Phân tích sự biến đổi axit amin thông qua so sánh trình tự axit amin của 55 chủng DEN - 1 năm 2017 với các chủng DEN - 1 gây bệnh tại Việt Nam (các năm 2005, 2008, 2015, 2016). Chúng tôi cũng so sánh với các chủng DEN - 1 gây bệnh ở một số nước trong khu vực và trên thế giới. Phân tích biến đổi di truyền của các chủng DEN - 1 bằng phần mềm MEGA (6.06) và ClustalX 2.1.

Tính khoảng cách hệ gen và so sánh độ tương đồng hệ gen giữa các chủng nghiên cứu và các chủng tham chiếu (47 chủng từ ngân hàng gen) được thực hiện bằng phương pháp MASH 2.0, sau đó vẽ biểu đồ Heatmap.

Xây dựng cây phát sinh loài: Trình tự hệ gen của 55 chủng DEN - 1 và 47 chủng tham chiếu (từ ngân hàng gen) được so sánh bằng phần mềm MAFFT (Multiple Alignment using Fast Fourier Transform). Toàn bộ trình tự đa hình 
nucleotide đơn (NSPs) được phân tách bằng phương pháp snp - sites. Hệ thống IQ - tree được ứng dụng để tạo cây phát sinh loài.

Các kỹ thuật sinh học phân tử được thực hiện tại - BVNĐTƯ, phối hợp với đơn vị nghiên cứu lâm sàng đại học Oxford tại Việt Nam.

\section{Xử lý số liệu}

Được thực hiện trên phần mềm SPSS 16.0. Các test Pearson Chi - Square và Fisher's Exact Test được sử dụng trong nghiên cứu.

\section{4. Đạo đức nghiên cứu}

Nghiên cứu được thông qua Hội đồng Đạo đức Bệnh viện Nhiệt đới Trung ương, số 23/ HĐĐĐ - NĐTƯ, ngày 01/07/ 2017.

\section{KẾT QUẢ}

\section{Kết quả xác định typ DENV và tải lượng virus}

Trong thời gian nghiên cứu, chúng tôi đã tuyển chọn 288 bệnh nhân được chẩn đoán xác định nhiễm DEN - 1. Trong đó , tải lượng virus của các mẫu bệnh phẩm DEN - $1>10^{3} \mathrm{copies} / \mathrm{ml}$ chiếm $98,6 \%, 4$ mẫu có tải lượng virus $\leq 10^{3}$ copies $/ \mathrm{ml}$.

\section{Giải trình tự hệ gen DEN - 1 và phân tích các biến đổi axit amin}

Bảng 1. Mức độ biến đổi axit amin trên hệ gen của các chủng DEN - 1

\begin{tabular}{lcc}
\hline Protein/gen & Số acid amin biến đổi/ tổng số & $\begin{array}{c}\text { Tỉ lệ biến đổi } \\
\text { (\%) }\end{array}$ \\
\hline Polyprotein & $157 / 3392$ & 4,6 \\
\hline PrM & $8 / 166$ & 4,8 \\
\hline E & $21 / 495$ & 4,2 \\
\hline C & $9 / 114$ & 7,9 \\
\hline NS1 & $21 / 352$ & 6,0 \\
\hline NS2A & $24 / 218$ & 11,0 \\
\hline NS2B & $7 / 130$ & 5,4 \\
\hline NS3 & $13 / 619$ & 2,1 \\
\hline NS4A & $6 / 150$ & 4,0 \\
\hline NS4B & $4 / 249$ & 1,6 \\
\hline NS5 & $43 / 899$ & 4,8 \\
\hline
\end{tabular}

Kết quả giải trình tự hệ gen cho thấy, 55 chủng DEN - 1 được giải trình tự thành công toàn bộ hệ gen với độ tin cậy cao, hệ gen mã hóa 10 protein (cấu trúc và không cấu trúc) được đọc lặp lại trung bình từ 300 lần - 20.000 lần. Đoạn gen mã hóa ba protein cấu trúc, đặc biệt protein $\mathrm{E}$ có độ lặp lại trên 1000 lần. Đoạn gen mã hóa NS1 có độ lặp lại rộng. Kết quả giải trình tự hệ gen đã xác định kích thước bộ gen hoàn chỉnh của các chủng DEN - 1 gồm 10.697 nucleotide và mã hóa một khung đọc mở gồm 3392 axit min (aa).

Kết quả phân tích hệ gen của 55 chủng DEN1 đã cho thấy biến đổi axit amin được phát hiện trên tất cả các gen (10 gen) thuộc vùng mã hóa. Tỉ lệ thay thế các axit amin tính chung trên toàn hệ gen là 4,6\%, sự đa dạng axit amin thấp nhất trên gen NS4B $(1,6 \%)$ và cao nhất trên gen NS2A $(11,0 \%)$ (Bảng 1). Tỉ lệ các chủng có biến đổi axit amin trên các gen dao động từ 1 - 6 chủng và tập trung 
vào một số vị trí nhất định, như vị trí 48, 125 trên gen PrM; vị trí 54 trên gen $\mathrm{E}$; vị trí 147 trên gen NS1; vị trí 45, 67, 126, 154 trên gen NS2A; vị trí 94 trên gen NS2B; vị trí 298 trên gen NS3; vị trí 47, 68 trên gen NS4A và vị trí 166, 167, 337, 609, 614, 821 trên gen NS5. So sánh độ tương đồng các vị trí biến đổi axit amin cho thấy, 55 chủng DEN - 1 năm 2017 có độ tương đồng cao với các chủng DEN - 1 gây bệnh năm 2015 - 2016 (được giải trình tự gen đồng thời) và năm 2008 tại Việt Nam. Nhưng có sự khác biệt tại hầu hết các gen, ở nhiều vị trí axit amin, so với chủng DEN - 1 gây bệnh tại Việt Nam năm 2005.

\section{Sự tương đồng trình tự bộ gen các chủng DEN - 1}

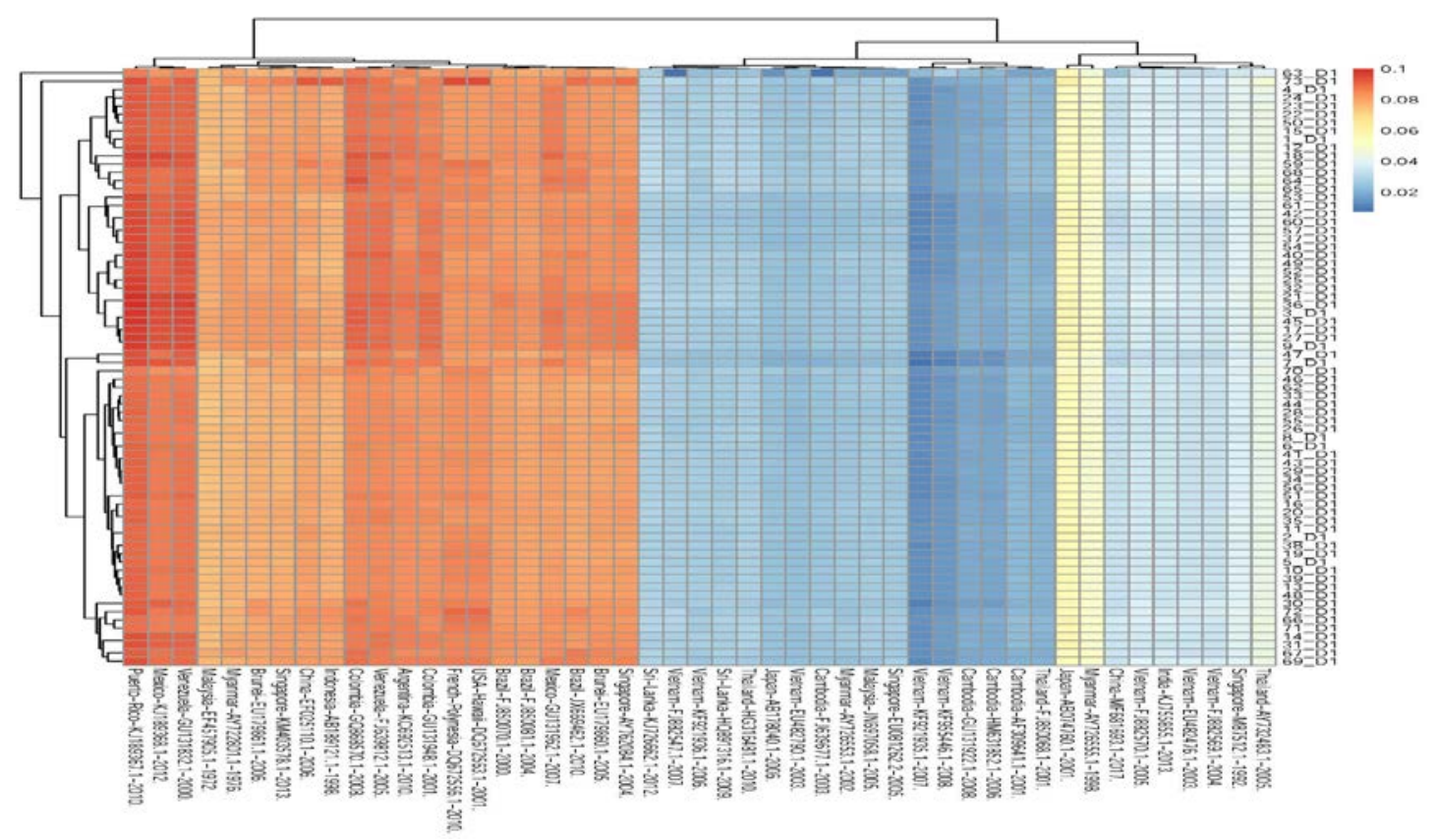

Hình 1. Phân cụm bộ gen của các chủng DEN - 1 năm 2017 (D1) và các chủng tham chiếu dựa trên khoảng cách MASH. Biểu đồ Heatmap minh họa sự tương đồng theo cặp giữa các chủng $\mathrm{D} 1$ và các chủng tham chiếu dựa trên thang màu nằm trong khoảng từ 0 (màu xanh) đến 0,1 (màu đỏ). Hai nhóm lớn được xác định: Nhóm 1 là màu xanh, thể hiện khoảng cách nhỏ giữa các mẫu D1 với mẫu tham chiếu, mức độ tương đồng hệ gen lớn. Nhóm 2 là màu cam và đỏ thể hiện khoảng cách giữa các mẫu lớn, mức độ tương đồng hệ gen nhỏ.

Biểu đồ Heatmap (Hình1) hiển thị thông tin dưới dạng ma trận, thể hiện giá trị khoảng cách giữa hai biến số: hàng - ký hiệu là D1 (gồm 55 chủng DEN - 1 năm 2017 và 18 chủng DEN - 1 năm 2015 - 2016) và cột (47 chủng DEN - 1 tham chiếu từ ngân hàng gen). Từ các dải màu xanh tới màu vàng và màu đỏ biểu thị sự tăng dần về giá trị khoảng cách bộ gen giữa các chủng DEN - 1 (của nghiên cứu và các chủng tham chiếu). Kết quả phân tích cho thấy có sự phân tách thành 2 nhóm màu rõ rệt, hợp lý về mặt địa lý. Nhóm 1 gồm toàn bộ vùng màu xanh biểu thị khoảng cách nhỏ (giữa các chủng DEN - 1 năm 2017 với chủng tham chiếu), do đó giữa các chủng có mức độ tương đồng bộ gen lớn. Ngược lại, nhóm màu cam và màu đỏ, thể hiện khoảng cách giữa các chủng là rất lớn, do đó độ tương đồng về bộ gen giữa các chủng nhỏ. Biểu đồ Heatmap cũng chỉ ra, trình tự hệ gen của các chủng DEN - 1 gây bệnh năm 2017 và các chủng gây bệnh năm 2015 - 2016 gần như trùng 
khớp với trình tự của các chủng DEN - 1 gây bệnh tại Việt Nam năm 2007 - 2008 (màu xanh đậm), cũng như có độ tương đồng cao với các chủng DEN - 1 gây bệnh tại Campuchia năm 2006, 2008. Các chủng năm 2017 có độ tương đồng trình tự hệ gen thấp so với các chủng DEN - 1 gây bệnh tại Nhật Bản và Myanmar (màu vàng). Ngoài ra, trình tự hệ gen còn có sự khác biệt khá lớn với các chủng DEN - 1 gây bệnh tại Brunei và Singapore (màu đỏ cam), mặc dù các chủng này cùng gây bệnh trong khu vực Đông Nam Á.

\section{Cây phát sinh loài}

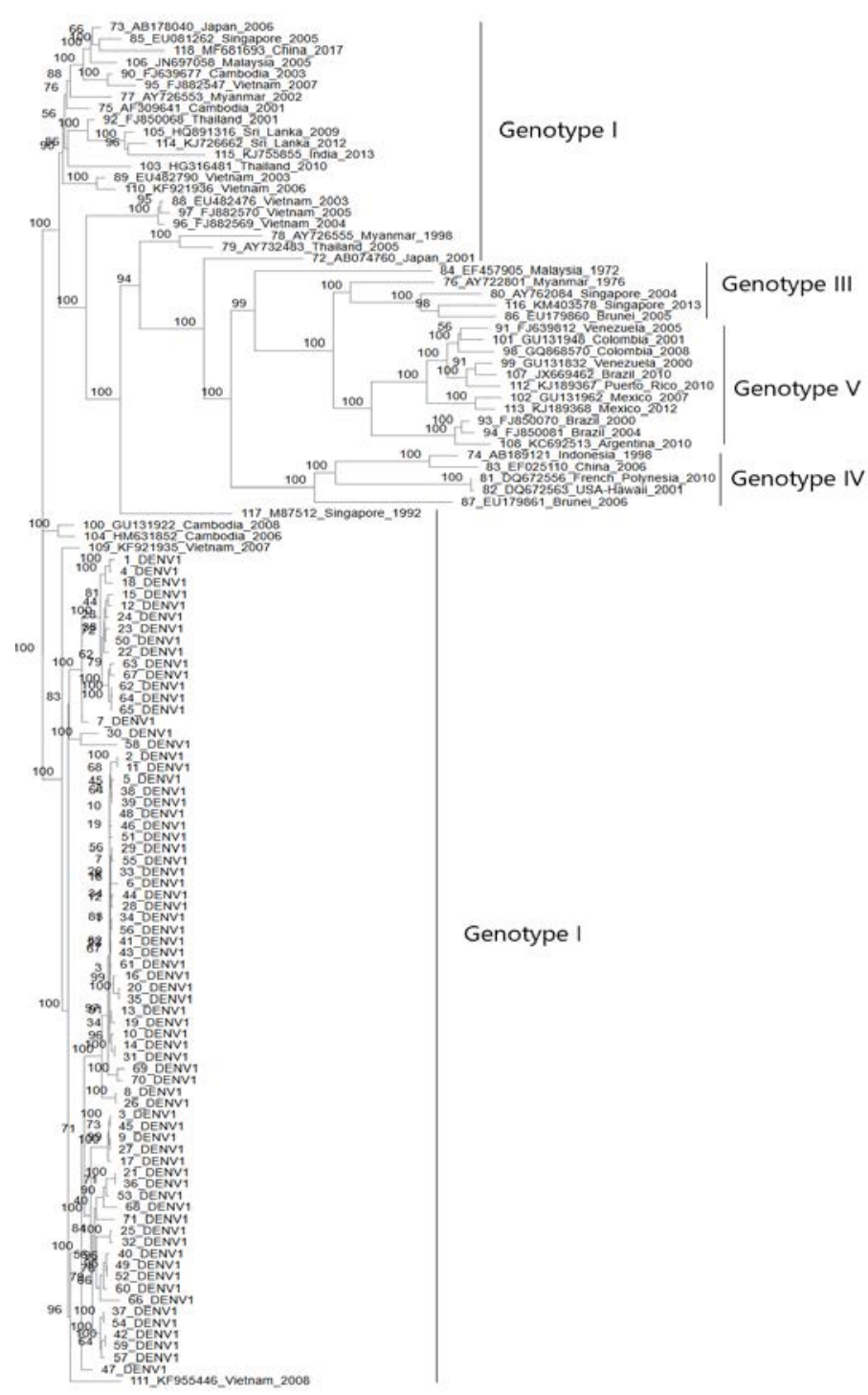

Hình 2. Cây phát sinh loài của các chủng DEN1. Xây dựng cây phát sinh loài dựa trên độ tương đồng trình tự bộ gen của 73 chủng DEN1 (năm 2017, 2016 và 2015) với 47 chủng tham chiếu. Các chủng trong nghiên cứu được ký hiệu là DENV1, các chủng gây bệnh tại Việt Nam trước đây và trên thế giới được ký hiệu bằng tên nước, số gia nhập GenBank và năm gây bệnh.

Cây phát sinh loài được xây dựng dựa trên trình tự nucleotide của toàn bộ hệ gen DEN - 1, bao gồm 55 chủng (gây dịch năm 2017), 18 chủng (năm 2015 - 2016) và 47 chủng tham chiếu từ ngân 
hàng gen (là các chủng DEN - 1 gây bệnh trước đây ở Việt Nam và một số khu vực trên thế giới). Các chủng trong nghiên cứu được đánh số từ 1 - 55, các chủng năm 2015 - 2016 và các chủng tham khảo từ ngân hàng gen ký hiệu lần lượt từ 56 đến 120. Kết quả phân tích cho thấy, 55 chủng DEN 1 gây bệnh năm 2017 có sự đồng nhất, không có sự pha trộn về nguồn gen và đều thuộc genotype 1. Các chủng này có mức tương đồng trình tự hệ gen rất cao với các chủng $D E N-1$ gây bệnh tại Việt Nam trong các năm 2007, 2008, 2015, 2016, cũng như có mối quan hệ di truyền gần với các chủng gây bệnh tại Campuchia (năm 2006, 2008). Kết quả cũng chỉ ra, 55 chủng DEN - 1 năm 2017 cùng nhóm với các chủng DEN - 1 gây bệnh trong khu vực, như Việt Nam $(2007,2008)$, Campuchia (2006, 2008), Thailand (2001, 2010), Myanmar (2002), Malaysia (2005), nhưng không cùng nhóm với các chủng gây bệnh tại Mỹ, Brazil, Mexico, Argentina, Venezuela, Comlombia. Tuy cùng một khu vực địa lý, nhưng các chủng DEN - 1 gây bệnh năm 2017 có sự khác biệt lớn với các chủng DEN - 1 gây bệnh tại Singapore (2013), Myanmar (1976), Malaysia (1972), Trung Quốc (2006), Indonesia (1998) và Brunei (2006) (Hình 2).

\section{4. Đối chiếu phân loại lâm sàng SXHD với mức độ biến đổi axit amin}

Bảng 2. Đặc điểm lâm sàng của bệnh nhân SXHD theo tải lượng virus và mức độ biến đổi axit amin

\begin{tabular}{|c|c|c|c|c|c|c|}
\hline Protein & $\begin{array}{l}\text { Vị trí } \\
\text { aa }\end{array}$ & $\begin{array}{c}\text { aa } \\
\text { tham } \\
\text { chiếu }\end{array}$ & $\begin{array}{c}\text { aa } \\
\text { biến đổi } \\
(\%)\end{array}$ & $\begin{array}{c}\text { SXHD không nặng } \\
n=21(\%)\end{array}$ & $\begin{array}{l}\text { SXHD nặng } \\
n=34(\%)\end{array}$ & $p$ \\
\hline PrM & 125 & 1 & $\mathrm{M}(32,7)$ & $12(57,1)$ & $6(17,6)$ & $0,02^{* *}$ \\
\hline$E$ & 54 & $\mathrm{~N}$ & $\mathrm{D}(80,0)$ & $17(81,0)$ & $27(79,4)$ & 1,0 \\
\hline C & 75 & $\mathrm{~N}$ & $S(98,2)$ & $20(95,2)$ & $34(100,0)$ & 0,38 \\
\hline NS1 & 147 & $A$ & $\mathrm{~T}(16,4)$ & $3(14,3)$ & $6(17,6)$ & 1,0 \\
\hline \multirow[t]{2}{*}{ NS2A } & 67 & $\mathrm{R}$ & $\mathrm{G}(49,1)$ & $4(19,0)$ & $23(67,6)$ & $\begin{array}{c}< \\
0,001^{* *}\end{array}$ \\
\hline & 126 & $\mathrm{H}$ & $Y(52,7)$ & $6(28,6)$ & $23(67,6)$ & $0,005^{* *}$ \\
\hline NS2B & 94 & $\mathrm{~T}$ & $\mathrm{~A}(49,1)$ & $4(19,0)$ & $23(67,6)$ & $\begin{array}{c}< \\
0,001^{* *}\end{array}$ \\
\hline NS3 & 298 & V & $M(18,2)$ & $4(19,0)$ & $7(20,6)$ & 1,0 \\
\hline \multirow[b]{2}{*}{ NS4A } & 47 & $\mathrm{R}$ & $\mathrm{K}(85,4)$ & $15(71,4)$ & $29(85,3)$ & 0,3 \\
\hline & 68 & $M$ & $\mathrm{~V}(29,1)$ & $12(57,1)$ & $4(11,8)$ & $\begin{array}{c}< \\
0,001^{* *}\end{array}$ \\
\hline NS4B & 29 & V & I $(5,4)$ & $3(14,3)$ & $0(0,0)$ & 0,051 \\
\hline \multirow[b]{3}{*}{ NS5 } & 166 & $\mathrm{~K}$ & $\mathrm{R}(18,2)$ & $3(14,3)$ & $7(20,6)$ & 0,72 \\
\hline & 614 & $E$ & $\mathrm{G}(18,2)$ & $6(28,6)$ & $4(11,8)$ & 0,16 \\
\hline & 821 & A & $\mathrm{T}(47,3)$ & $3(14,3)$ & $23(67,6)$ & $\begin{array}{c}< \\
0,001^{* *}\end{array}$ \\
\hline
\end{tabular}

\section{${ }^{* *}$ Pearson Chi - Square * Fisher's Exact Test}

Chúng tôi chọn ra 14/157 vị trí axit amin có tỉ lệ biến đổi cao, đại diện cho 10 gen vùng mã hóa, để 
so sánh với các mức độ biểu hiện bệnh trên lâm sàng. Kết quả cho thấy, $6 / 14$ vị trí thay thế axit amin có liên quan với phân loại lâm sàng nặng và không nặng (khác biệt có ý nghĩa thống kê, $p$ $<0,01$ ) (Bảng 2). Các vị trí biến đổi axit amin có liên quan với sự khác biệt trên lâm sàng là 125 (PrM); 67, 126 (NS2A); 94 (NS2B); 68 (NS4A) và 821 (NS5).

\section{BÀN LUẬN}

Trong vụ dịch năm 2017 có sự lưu hành đồng thời của hai typ DEN - 1 và DEN - 2, tuy nhiên typ DEN - 1 vẫn là typ virus đóng vai trò gây bệnh chính (chiếm 98,3\%) trong vụ dịch này. ${ }^{8}$ Các kết quả giám sát virus học trong gần hai thập kỷ qua cũng ghi nhận DEN - 1 và DEN - 2 vẫn là hai typ virus gây bệnh chiếm ưu thế, trên toàn bộ lãnh thổ Việt Nam. ${ }^{7,10}$ Hơn thế nữa, các kết quả nghiên cứu cũng cho thấy kể từ năm 2010 đến nay, tỉ lệ lưu hành của typ DEN - 1 có xu hướng tăng dần qua các vụ dịch tại Việt Nam. ${ }^{6,10}$ Trong vụ dịch SXHD năm 2017 kết quả nghiên cứu của chúng tôi (trên hai miền Bắc và Nam) cho thấy typ $\mathrm{DEN}$ - 1 chiếm ưu thế $(98,3 \%)$ hơn hẳn các typ khác. Vì vậy, việc nghiên cứu về sinh học phân tử của typ DEN 1 có thể có ích trong đánh giá về mức độ ảnh hưởng của DEN - 1 đến vụ dịch 2017.

Các DENV đã được ghi nhận là virus mang gen $A R N$ có tốc độ đột biến trung bình rất cao (chỉ sau HIV và virus influenza), khoảng 7,5×10 - 4 đột biến/vị trí/năm. ${ }^{11,12}$ Tốc độ đột biến (tiến hóa) cũng đã được chứng minh phụ thuộc vào mức độ lưu hành, cũng như tốc độ nhân lên của DENV ở con người. ${ }^{12}$ Chúng tôi đã tiến hành phân tích hệ gen của 55 chủng DEN - 1 gây dịch năm 2017. Kết quả cho thấy tỉ lệ biến đổi các axit amin trên toàn bộ hệ gen cao hơn $(4,6 \%)$ (Bảng 1), nếu so với kết quả phân tích trong các vụ dịch trước đây (chỉ dao động từ $2,4 \%$ đến $3,7 \%$ ). ${ }^{3,11}$ Như vậy, có thể sự đa dạng các acid amin đã gây ra tình trạng nặng của vụ dịch SXHD năm 2017.

Tuy nhiên khi so sánh về độ tương đồng các điểm biến đổi axit amin giữa các chủng trong vụ dịch năm 2017 với các chủng tham khảo, chúng tôi nhận định các chủng DEN - 1 gây bệnh năm 2017 có thể vẫn là các chủng gây bệnh năm 2015, 2016 và có chung nguồn gốc với các chủng DEN - 1 gây bệnh tại Việt Nam năm 2008, nhưng không chung nguồn gốc với chủng gây bệnh tại Việt Nam năm 2005. Chúng tôi cũng so sánh với các chủng DEN - 1 gây bệnh ở một số nước trong khu vực như Thái Lan (2010), Campuchia (2008), Trung Quốc (2017) và Brazil (2010) là một khu vực có khoảng cách địa lý cách xa Việt Nam. Kết quả cho thấy cũng có sự tương đồng nhất định ở các vị trí thay thế axit amin.

Bản đồ heatmap đã cho thấy mối quan hệ di truyền giữa 55 chủng DEN - 1 gây bệnh năm 2017 với các chủng tham chiếu. Số liệu phân tích đã chứng minh các chủng DEN - 1 năm 2017 (Hình 1) có độ tương đồng về bộ gen rất cao với các chủng DEN - 1 năm 2015 - 2016 và các chủng gây bệnh tại Việt Nam năm 2007 - 2008. Ngoài ra, các chủng này cũng có mối quan hệ di truyền gần gũi với các chủng gây bệnh tại Campuchia (2006, 2008). Như vậy, các chủng DEN - 1 năm 2017 vẫn là các chủng nội địa.

Toàn bộ 55 chủng DEN - 1 trong nghiên cứu, 18 chủng tham chiếu năm 2015 - 2016 và các chủng gây bệnh năm 2007 - 2008 được xếp cùng một nhánh riêng biệt trên cây phát sinh loài, đều được xác định thuộc genotype 1 (Hình 2). Điều đó cũng khẳng định thêm các chủng DEN - 1 gây dịch năm 2017 là các chủng lưu hành và gây bệnh tại Việt Nam. Các chủng DEN - 1 năm 2017 cũng có chung nguồn gốc với các chủng gây bệnh tại Campuchia (2006, 2008). Như vậy, các chủng DEN - 1 đã trở thành chủng lưu hành đặc hữu tại Việt Nam và ít có 
sự biến động về mặt di truyền trong trong hai thập kỷ qua. ${ }^{13}$ Khi đối chiếu 14 vị trí axit amin có tỉ lệ biến đổi cao với lâm sàng, chúng tôi ghi nhận 6/14 vị trí biến đổi trên hệ gen của các chủng DEN - 1 có liên quan với biểu hiện lâm sàng nặng và không nặng. Cụ thể, trên những bệnh nhân được phân loại SXHD nặng có sự thay đổi $67,6 \%$ các axit amin tại các vị trí 67 , 126 (NS2A); 94 (NS2B) và 821 (NS5). Ngược lại, trong SXHD không nặng chỉ có sự thay đổi $57,1 \%$ số axit amin tại các vị trí 125 (PrM); 68 (NS4A) (Bảng 2).

Các nghiên cứu và $Y$ văn cũng đã ghi nhận sự đa dạng biến đổi các vị trí axit amin có thể dẫn đến thay đổi khả năng gây bệnh và độc lực của DENV. ${ }^{3,4}$ Descloux cho rằng biểu hiện lâm sàng có tương quan với sự đa dạng di truyền của DENV trong vật chủ. ${ }^{4}$ Một số nghiên cứu cũng chỉ ra các biến đổi trên gen cấu trúc (PrM, E) và một số gen không cấu trúc (NS2B, NS3) có liên quan tới mức độ nghiêm trọng của bệnh. ${ }^{14,15}$ Tuy nhiên, các nghiên cứu chưa đề xuất về các vị trí thay thế axit amin có liên quan với mức độ nặng trên lâm sàng. Cho đến nay, chưa có nhiều nghiên cứu về mối liên quan này, vì vậy cần có thêm các nghiên cứu trong tương lai.

\section{KÉT LUÂN}

Qua kết quả nghiên cứu về đặc điểm sinh học phân tử DENV gây dịch năm 2017, chúng tôi đưa ra kết luận DEN - 1 là typ virus chiếm ưu thế trong vụ dịch và các chủng gây bệnh có mức độ đa dạng di truyền cao. Xét về nguồn gốc phát sinh loài, các chủng này vẫn là chủng lưu hành và gây bệnh tại Việt Nam. Một số vị trí thay thế axit amin có liên quan tới SXHD nặng.

\section{TÀI LIẸU THAM KHẢO}

1. World Health Organization. Dengue: Guidelines for Diagnosis, Treatment, Prevention and Control. Geneva: New Edition. 2009.

2. Julien L. and Shee - Mei LoK. The
Structural Biology of Dengue Virus. In: Duane J. Gubler, Eng E. Ooi, Subhash Vasudevan, Jeremy Farrar, Editor. Dengue and Dengue Hemorrhagic Fever. CPI Group Ltd, Croydon, CRO 4YY: Printed and bound in the UK. 2014; 365 - 376.

3. Tang $Y$, Rodpradit $P$, Chinnawirotpisan $P$, et al. Comparative analysis of full - length genomic sequences of 10 dengue serotype 1 viruses associated with different genotypes, epidemics, and disease severity isolated in Thailand over 22 years. Am J Trop Med Hyg. 2010; 83 (5):156 - 65.

4. Descloux E, Cao - Lormeau V. M, Roche $C$, De Lamballerie $X$. Dengue 1 diversity and microevolution, French Polynesia 2001 - 2006: connection with epidemiology and clinics. PLOS Negl Trop Dis. 2009; 3 (8). e493.

5. Bộ Y tế. Hướng dẫn chẩn đoán, điều trị sốt xuất huyết Dengue. Ban hành kèm theo Quyết định số 3705/QĐ - BYT ngày 22 tháng 08 năm 2019 của Bộ trưởng Bộ Y tế, 2019.

6. Đặng Thị Thúy, Annette Fox, Bùi Vũ Huy, et al. Đặc điểm lâm sàng bệnh sốt xuất huyết dengue theo các typ virus dengue gây bệnh. Tạp chí y hoc dự phong. 2013; 2 (137): 30 - 34.

7. Cao Minh Thắng, Vũ Thiên Thu Ngữ, Huỳnh Phương Thảo, et al. Giám sát vi rút học bệnh sốt xuất huyết dengue trong chương trình mục tiêu quốc gia phòng chống sốt xuất huyết dengue tại khu vực phía Nam Việt Nam trong giai đoạn 2005 - 2014. Tạp chí y hoc dự phong. 2015; Tập XXV, số 5 (165): 42 - 46.

8. Huong Van Nguyen PQTT, Nguyen $\mathrm{TH}, \mathrm{Vu} \mathrm{GT}$, et al. Knowledge, Attitude and Practice about Dengue Fever among Patients Experiencing the 2017 Outbreak in Vietnam. Int J Environ Res Public Health. 2019; 16:976 - 88.

9. Keats J. J, Cuyugan L, Adkins J, Liang W. S. Whole Genome Library Construction for Next Generation Sequencing. Methods Mol 
Biol. 2018; 1706:151 - 161.

10. Nguyễn Mạnh Hùng, Trần Thị Ngọc Ánh, Nguyễn Thị Kiều Anh và cộng sự. Sự lưu hành và một số đặc điểm dịch tễ các týp vi rút dengue gây bệnh sốt xuất huyết tại hà nội, giai đoạn 2015 - 2017. Tạp chí Y học dụp phòng. 2017; 28 (5): 88 - 96.

11. Benediktus Yohan, Puspa Wardhani, Hidayat Trimarsanto, et al. Genomic analysis of dengue virus serotype 1 (DENV-1) genotypes from Surabaya, Indonesia. Virus Genes. 2018; 54 (3). doi: 10. 1007/s11262 - 018 - 1558 - z.

12. Costa R. L, Voloch C. M, Schrago C. G. Comparative evolutionary epidemiology of dengue virus serotypes. Infect Genet Evol. 2012; 12 (2): 309 - 14.
13. Vũ Thiên Thu Ngữ, Phạm Thị Thu Hằng, Hoàng Thị Như Đào và cộng sự. Phân tích di truyền của vi rút dengue lưu hành tại khu vực phía Nam Việt Nam năm 2014 - 2015. Tạp chí y học dự phòng. 2015; Tập XXV, số 5 (165): 47 - 53.

14. Rodriguez - Roche R, Blanc $\mathrm{H}$, Bordería A. V, et al. Increasing Clinical Severity during a Dengue Virus Type 3 Cuban Epidemic: Deep Sequencing of Evolving Viral Populations. J Virol. 2016; 90 (9): 4320 - 4333.

15. Jiang L, Ma D, Ye C. , Et al. Molecular Characterization of Dengue Virus Serotype 2 Cosmospolitan Genotype From 2015 Dengue Outbreak in Yunnan, China. Front Cell Infect Microbiol. 2018; 8:219.

\section{Summary MOLECULAR CHARACTERISTICS AND RELATIONSHIP WITH CLINICAL SEVERITY OF DENGUE VIRUS TYPE 1 IN THE 2017 OUTBREAK}

This study was conducted to investigate some of the molecular characteristics and correlation with clinical severity of DEN - 1 strains in the 2017 outbreak. Multi - center study was implemented from July 2017 to December 2017 at the National Hospital for Tropical Diseases and Hospital for Tropical Diseases, Ho Chi Minh City on 188 dengue hemorrhagic fever patients $\geq 6$ years old with PCR (+) with DEN - 1. Results showed that the genome of 55 strains of DEN - 1 causing the outbreak in 2017 was successfully decoded. Genome included 10,697 nucleotides, encoded an open reading frame for 3392 amino acid. DEN - 1 strains belonged to genotype 1 and had a high level of amino acid variation in most genes (4.6\%). The genetic origin was still the strains that were reported previously in Vietnam. There was a relationship between the four amino acid substitutions 67, 126 (NS2A); 94 (NS2B) and 821 (NS5) with severe dengue hemorrhagic fever. In conclusion, research has showed the origin, genetic variation of the DEN - 1 strains in Vietnam and the relationship between amino acid substitutions with clinical levels.

Keywords: Full - length genome, dengue virus type 1 (DEN - 1), genetic variants. 